\title{
Proximate, caloric, nitrogen and mineral composition of bodies of some tropical bats
}

\section{Eugene H. Studier, ${ }^{*}$ Steven H. Sevick* and Don E. Wilson $\dagger$}

${ }^{*}$ Department of Biology, University of Michigan-Flint, Flint, MI 48502-2186, U.S.A.; and

$\uparrow$ National Museum of Natural History, Smithsonian Institution, Washington, D.C. 20560, U.S.A.

Proximate (live mass, water, lipid, ash, non-fat organic), caloric, nitrogen, and mineral (sodium, potassium, calcium, magnesium, and iron) concentrations and total body content of individuals of 24 species of Neotropical and Paleotropical bats were determined. Mass-related, concentration patterns were found for all measured variables, except iron. Concentrations increase with size for nitrogen, calcium, and magnesium but are concave, opening upward, for sodium and potassium. These last two elements reach minimal concentrations in bats weighing about 22 and $28 \mathrm{~g}$ dry mass, respectively. Total body content of nitrogen and minerals was compared with amounts in similar-sized birds and tetrapodal mammals.

Key words: Bat; Bird; Mammal; Body composition; Nitrogen; Sodium; Potassium; Calcium; Magnesium; Iron.

Comp. Biochem. Physiol. 109A, 601-610, 1994.

\section{Introduction}

Studies of body composition of tropical and temperate bats have been limited mainly to variables such as caloric content and lipid levels, which are related to energetics (McNab, 1976). Similar emphases have been applied to other small mammals (Studier, 1979) and birds (Holmes, 1976). That trend relates directly to the implied critical importance of energetics as a probable limiting factor in maintaining adequate nutritional budgets in small endotherms. Recent investigations in birds (Hungerford et al., 1993), other small mammals (Randolph et al., 1991; Willig and Lacher, 1991), and bats (Studier and Kunz, 1994)

Correspondence to: E. H. Studier, Department of Biology, University of Michigan-Flint, Flint, MI 48502-2186, U.S.A. Tel. 8107623360 .

Received 31 January 1994; accepted 10 June 1994. have expanded studies of nutrition to include nitrogen and mineral requirements and budgets. Just as body energy concentration (Cummins and Wuycheck, 1971) is essential in the calculation of energy budgets, similar estimates of nitrogen and mineral levels are necessary to establish budgets for those nutrients. Limited data are available on nitrogen and mineral concentration and content in small birds (Bilby and Widdowson, 1971; Sturges et al., 1974; Hagen et al., 1976; Pinowski et al., 1983; Taylor and Konarzewski, 1992) and other mammals (Gentry et al., 1975); however, no data have been published on levels of those elements in bats. We present data on live mass, water, fat, and non-fat organic matter, as well as on nitrogen, sodium, potassium, calcium, magnesium and total iron levels in a broad sample of tropical bat 
species. Portions of those data are compared with data on temperate bats. Nitrogen and mineral levels in bats are compared with levels in small, tetrapodal mammals and with small birds to investigate whether bat body composition reflects that of other mammals, or if composition is modified by physical demands of flight.

\section{Materials and Methods}

Paleotropical bats were collected by members of the 1979 Taylor South Seas Expedition from the Natural History Museum of Los Angeles County from midJune through early August 1979 from various sites on New Ireland and New Britain Islands in Papua/New Guinea. Those specimens were sent to us as uniformly and finely ground whole bats in individual ziplock bags with labels indicating live and dry mass and gender of each specimen. These samples were re-dried to constant mass at $50-60^{\circ} \mathrm{C}$ before analyses.

Neotropical bats were mist-netted between 18.00 and $19.30 \mathrm{hr}$ during July 1992 at various sites near the Amazon or Napo Rivers downstream from Iquitos, Pcrú. Captured bats were held for $1-3 \mathrm{hr}$ in monkscloth or burlap bags, allowing the gut to empty for feces collection. Selected male bats and female bats, which were not obviously pregnant or lactating, were euthanized, weighed to $0.01 \mathrm{~g}$ (American Scientific Battery-Powered Scale) to determine live mass, then partially dried. Upon return to the lab, bats were dried to a constant weight at $50-60^{\circ} \mathrm{C}$, and dry mass (DM) was determined to $0.1 \mathrm{mg}$. Dried bats were individually ground to a uniform mixture in a Braun coffee grinder.

Depending on the total DM of each specimen, duplicate or triplicate $0.5 \mathrm{~g}$ subsamples (weighed to $0.1 \mathrm{mg}$ ) were analyzed for fat, non-fat organic matter, and ash content. Fat was extracted with 50 volumes of petroleum ether in $125 \mathrm{ml}$ Erlenmeyer flasks that were mixed on rotary shakers for $4 \mathrm{hr}$. Extracted samples were then filtered and rinsed with petroleum ether through pre-weighed filter paper, then dried to constant mass in a hood, and sample fat was determined by DM loss. Fats extracted with petroleum ether are primarily stored, neutral body fats, not including all polar membrane lipids. These dried samples were then burned in a muffle furnace at $500^{\circ} \mathrm{C}$ for $6 \mathrm{hr}$ and re-weighed to determine non-fat organic matter and ash content. Individual reported values are means of two or three replicates. Water and fat indices (as $\mathrm{g} / \mathrm{g}$ lean DM) were calculated from those values. Caloric density (kcal/g DM) was calculated using energy equivalents of $9.4 \mathrm{kcal} / \mathrm{g}$ fat and $4.1 \mathrm{kcal} / \mathrm{g}$ non-fat organic matter. These procedures are reviewed by Pierson and Stack (1988).

Depending on the DM of each specimen, duplicate or triplicate $250 \mathrm{mg}$ (weighed to $0.1 \mathrm{mg}$ ) samples were digested in $250 \mathrm{ml}$ volumetric flasks using $2.5 \mathrm{ml}$ of boiling, concentrated $\mathrm{H}_{2} \mathrm{SO}_{4}$ followed by $7.5 \mathrm{ml}$ of a $2: 1(\mathrm{v} / \mathrm{v})$ mixture of $30 \% \mathrm{H}_{2} \mathrm{O}_{2}$ and concentrated $\mathrm{H}_{2} \mathrm{SO}_{4}$. After appropriate dilution, aliquots of those digestions were analyzed for nitrogen by Nesslerization (Treybig and Haney, 1983), for sodium and potassium levels by flame emission spectrophotometry, and for calcium, magnesium and total iron by atomic absorption spectrophotometry. Details of these analyses are given in Studier and Sevick (1992). Average values for replicates are reported.

Data were stored in Lotus files and analyzed using SYSTAT (Wilkinson, 1989). Most data previously reported for nitrogen and mineral concentrations and total content in each group compared (bats, other mammals, small birds) are from small species ( $<40 \mathrm{~g} \mathrm{DM}$ ), with very few data for larger species in any of those groups. Reported regession analyses are, therefore, certainly more precise at the lower end of the DM scalc. SYSTAT regression analyses allow for identification of data points that are statistical outliers or exert significant leverage within the analysis. No such data points were found; therefore, the few data for bats of large mass do not unduly influence the reported regession lines. Linear and polynomial regression analyses were performed, and only significant regression coefficients are reported for 200 individuals of 24 species of bats and on average values for each of 25 species of birds. Published linear regression analyses for 26 or 27 species of rodents and shrews were used for comparison with bird and bat data. Our data might have been analyzed to yield allometric equations after log-log trans- 
formation; and, many physiological functions have been shown to be exponentially related to size (Peters, 1983); however, such analysis would not be comparable with previously published data on body composition.

Since our primary interest in these data is body concentrations and total content of nitrogen and minerals, data for those elements have been analyzed and discussed more thoroughly than proximate and caloric data. Reduced data, shown in Appendix 1, will allow sexual dimorphism differences to be compared, will allow measured variables to be re-calculated in other units, e.g. ash-free or fat-free DM, for comparison to literature data reported in such units, and will allow calculation of regression equations (on transformed data, if desired) or other statistical testing on species averages.

\section{Results}

Reduced data for all measured and calculated variables for all bats analyzed are given by species and gender in Appendix 1. Data for individual bats are available on diskette or in hard copy from the authors upon request. Body water content (water in $\mathrm{g} / 100 \mathrm{~g}$ live mass) increases slightly, but significantly $(F=8.643$, d.f. $\left.=192, r^{2}=0.043, P=0.00369\right)$, with increasing size (DM in $\mathrm{g}$ ) as expressed by:

$$
\begin{aligned}
\text { Water } & =0.0006659 \mathrm{DM}^{2}+67.19 \\
& ( \pm 0.0002265) \quad( \pm 0.18)
\end{aligned}
$$

where values in parentheses are standard errors of the regression coefficient(s) and intercept. The very low $r^{2}$ value, however, indicates that water content and the other relations of proximate variables to body size have very low prediction accuracy. Body fat (fat in $\mathrm{g} / 100 \mathrm{~g}$ live mass) and fat index (FIND in $\mathrm{g} / \mathrm{g}$ lean $\mathrm{DM}$ ) are both inversely related to body size as DM in $\mathrm{g}\left(F=5.290\right.$, d.f. $=192, \quad r^{2}=0.027$, $P=0.0225 ;$ and, $F=3.615, \quad$ d.f. $=192$, $r^{2}=0.037, \quad P=0.0288$, respectively) as shown by the equations:

$$
\begin{aligned}
\text { Fat }= & -0.0004127 \mathrm{DM}^{2}+3.719 \\
& ( \pm 0.0001794) \quad( \pm 0.139)
\end{aligned}
$$

and

\section{FIND $=$}

$$
\begin{gathered}
-0.0000408 \mathrm{DM}^{2}+0.00185 \mathrm{DM}+0.119 . \\
( \pm 0.0000163) \quad( \pm 0.00100) \quad( \pm 0.008)
\end{gathered}
$$

Total body organic content $(\mathrm{TORG}=$ nonfat organic matter + fat in $\mathrm{g} / 100 \mathrm{~g}$ live mass) is also inversely related to body size as DM in $\mathrm{g} \quad(F=6.942 ; \quad$ d.f. $=192$, $r^{2}=0.035, P=0.00911$ ) as follows:

$$
\begin{aligned}
\text { TORG } & =-0.0005583 \mathrm{DM}^{2}+27.46 \\
( \pm 0.0002119) & ( \pm 0.16)
\end{aligned}
$$

The only other variables found to relate to size were most measured elements. Results of polynomial regression analyses of body concentrations (in $\mathrm{mg} / \mathrm{g} \mathrm{DM}$ ) of measured elements as potential functions of body size (DM), with the exception of total iron, which exhibits no relationship, are best expressed by linear or curvilinear equations that are poorly predictive

Table 1. Significant polynomial regression equations of element $(E)$ concentration (in $\mathrm{mg} / \mathrm{g}$ dry mass) as functions of size (in $\mathrm{g}$ dry mass) in tropical bats

\begin{tabular}{lccccc}
\hline$E$ & $a$ & $b$ & $c$ & $F$ & $r^{2}$ \\
\hline $\mathrm{N}$ & 0.002275 & & 155.03 & 9.679 & 0.046 \\
& \pm 0.000731 & & \pm 0.55 & & \\
$\mathrm{Ca}$ & & 0.2789 & 13.976 & 187.33 & 0.482 \\
& & \pm 0.0204 & \pm 0.310 & & \\
$\mathrm{Mg}$ & 0.0001086 & & 0.9357 & 94.904 & 0.321 \\
& \pm 0.0000111 & & \pm 0.0084 & & \\
$\mathrm{Na}$ & 0.0003819 & -0.01659 & 4.389 & 12.195 & 0.109 \\
& \pm 0.0000850 & \pm 0.00522 & \pm 0.043 & & \\
$\mathrm{~K}$ & 0.001697 & -0.09475 & 9.823 & 25.776 & 0.205 \\
& \pm 0.000236 & \pm 0.01451 & $\pm \mathbf{0 . 1 1 9}$ & & \\
\hline
\end{tabular}

Data for 24 species are included. Values are coefficients and intercepts $( \pm S E)$ for lines of the form $y=a x^{2}+b x+c$. In each case, d.f. $=199$ and $P<0.0001$, except for nitrogen (N) where $P=0.0021$. 
Table 2. Significant polynomial regression equations for total body element $(E)$ level (in $\mathrm{mg}$ ) as functions of size (in g dry mass) in tropical bats

\begin{tabular}{lccccc}
\hline$E$ & $a$ & $b$ & $c$ & $F$ & $r^{2}$ \\
\hline $\mathrm{N}$ & 0.1841 & 152.9 & -2.565 & 65619.0 & 0.998 \\
& \pm 0.0171 & \pm 1.1 & \pm 8.628 & & \\
$\mathrm{Fe}$ & & 0.3537 & 0.3908 & 1403.8 & 0.875 \\
$\mathrm{Ca}$ & 0.3189 & \pm 0.0094 & \pm 0.1438 & & \\
& \pm 0.0135 & \pm 0.83 & \pm 6.439 & 3799.9 & 0.974 \\
$\mathrm{Mg}$ & 0.008858 & 0.8157 & 0.2478 & 7111.4 & 0.986 \\
& \pm 0.00423 & \pm 0.0260 & \pm 0.2132 & & \\
$\mathrm{Na}$ & 0.01882 & 3.747 & 1.785 & 12008.0 & 0.992 \\
& \pm 0.00118 & \pm 0.073 & \pm 0.595 & & \\
$\mathrm{~K}$ & 0.06539 & 6.817 & 8.782 & 7736.6 & 0.987 \\
& \pm 0.00323 & \pm 0.198 & \pm 1.629 & & \\
\hline
\end{tabular}

Data for 24 species are included. Values are coefficients and intercepts $( \pm S E)$ for lines of the form $y=a x^{2}+b x+c$. In each case, d.f. $=199$ and $P<0.0001$.

(Table 1). Relationships of total body content (in $\mathrm{mg}$ ) of measured elements to body size (DM) show highly predictive positive linear or curvilinear relationships (Table 2).

\section{Discussion}

The slight increase in relative body water with increasing size found in the tropical bats tested may be associated with decreasing surface area-to-mass ratio that accompanies increasing size in similarly shaped organisms, and consequent relative decrease in evaporative water loss rates (Studier, 1970). Lack of a significant rclationship of water index ( $\mathrm{g}$ water/g lean DM) to size, however, argues strongly against that explanation. The slight increase in relative body water is more likely related to observed slight decreases in body fat fraction, i.e. body water is constant when expressed on a fat-free basis.

Data, reviewed by McNab (1976), show that fat levels in temperate zone bats cycle seasonally and are generally higher in females than in males. His study on limited numbers of neotropical bat species supports gender related trends for insectivorous species and seasonal trends for bats of varying feeding habits; however, seasonal trends are much less dramatic in bats that feed primarily on food of plant origin. Values reported here (Appendix 1) agree well with very low fat levels found by McNab (1976) for bats collected in July. The significant slight decrease in fat index, which, like the water index, is related to lean dry mass, implies that an actual decrease in body fat occurs with increased body size.

Although sample size is small, Chiroderma villosum, especially females, contain much more fat, on either a live mass or lean dry mass basis (Appendix 1), than other species tested. For a fruit eating species (Gardner, 1977), especially in July, such high body fat levels are highly unusual and suggest marked differences in occurrence and activity of enzymes (fatty acid synthetase complex) required for converting carbohydrates to fat.

Many fruit-feeding bats seem to lack the ability to store excess energy as fat and, by storing that excess as glycogen, possess few energy reserves (Studier and Wilson, 1991). Another exception may be the genus Leptonycteris, individuals which deposit large stores of subcutaneous fat as well. However, both species of Leptonycteris are subtropical, and at least some populations are migratory (Arita and Wilson, 1987).

Lack of a relationship of total ash or non-fat organic matter to size also supports the interpretation that body water is constant when expressed on a fat-free basis. In view of the direct positive relations found for most tested body element concentrations (Table 1), a positive relationship of ash fraction to body size is expected. Greater precision in measuring slight differences in concentrations of elements compared with determination of ash may explain lack of statistical significance.

Lack of a relationship of total ash to size, when coupled to the inverse relation of fat 
to size, explains the slight negative correlation of total body organic level to body size.

Lack of an inverse relationship of caloric density to size is surprising in view of the inverse relation of fat to size. Gender relationships are strongly correlated with fat content, with females showing higher caloric content than males in every case but one. Carollia perspicillata males show slightly elevated caloric densities, as well as slightly higher fat and fat index values.

Body nitrogen concentrations increase with size in bats (Table 1) and, perhaps, in other small mammals (see Munro, 1969; Gentry et al., 1975). Insufficient data on body nitrogen concentrations for birds are available to complete an appropriate regression analysis; however, data for individual species (Bilby and Widdowson, 1971; Hagen et al., 1976; Pinowski et al., 1983; Taylor and Konarzewski, 1992; and Hungerford et al., 1993) fall very near the regression equations for bats and other small mammals. Since body nitrogen is often assumed to be almost entirely present as protein and most body protein is in muscle, increases in nitrogen concentration with increasing size strongly suggest relatively greater body musculature with increasing size in all small vertebrate endotherms.

Of the minerals measured, only total iron concentration exhibited no relationship to size. Because total blood volume and hemoglobin mass relate directly and linearly to size in mammals (Peters, 1983), iron concentration should be constant and not size-dependent. No relationship exists between body iron concentration and body size in other small mammals (Gentry et al., 1975) and our analyses of data available for small birds (Bilby and Widdowson, 1971; Sturges et al., 1974; Hagen et al., 1976; Pinowski et al., 1983; Taylor and Konarzewski, 1992; Hungerford et al., 1993) indicate a similar lack of relationship in that class. Average body iron concentrations in small birds $(0.308 \mathrm{ppt} \mathrm{DM}$; Sturges et al., 1974) are identical to concentrations in non-bat, small mammals (0.303 ppt DM; Gentry et al., 1975) and both are lower than most values for small bats (Appendix 1).

Among all bats tested, body sodium and potassium concentrations generally increase with body size (Table 1). The relationships, however, are curvilinear with minimal (Studier et al., 1975) body concentrations of both sodium $(=4.03 \mathrm{ppt}$ DM at $=21.7 \mathrm{~g} \mathrm{DM})$ and potassium $(=7.18 \mathrm{ppt}$ $\mathrm{DM}$ at $27.9 \mathrm{~g} \mathrm{DM}$ ). If data for bats of body $\mathrm{DM}<50 \mathrm{~g}$ are analysed (Appendix 1), no relationship of either mineral to size is found. No relation for either mineral to size was found in other small mammals (Gentry et al., 1975), and analyses of data for birds (from the same sources given for iron above) show no relation to size for potassium and a negative relation for sodium concentrations to body size $(F=13.51$; d.f. $=23, P=0.0013, r^{2}=0.381$, regression coefficient $\pm \mathrm{SE}=-0.1355 \pm 0.0037)$. Average body sodium concentrations in birds (4.10 ppt DM; Sturges et al., 1974) and non-bat small mammals (3.68 ppt DM; Gentry et al., 1975) compare favorably with minimal values for bats; and minimal potassium values in bats are similar to those for birds (8.12 ppt DM; Sturges et al., 1974), but somewhat lower than in other mammals (11.5 ppt DM; Gentry et al., 1975).

In bats, both calcium and magnesium body concentrations increase curvilinearly with body size, with minimal concentrations found at the origin (Table 1). Because concentrations of both elements increase rapidly with DM, comparisions with average values for birds (Sturges $e t a l$, 1974) and other small mammals (Gentry et al., 1975) are meaningless. Lack of a relationship of concentrations of each of these minerals to body size in mammals (Gentry et al., 1975) and birds (from the same sources given previously for iron) is very surprising since skeletal mass has been shown to relate allometrically (as an exponential function $>1$ ) to body size in many vertebrates (Kayser and Heusner, 1964; Reynolds and Karlotski, 1977; Prange et al., 1979; Anderson et al., 1979).

At similar dry masses, total body nitrogen content in bats (Table 2) exceeds values for other mammals (Gentry et al., 1975). Greater nitrogen levels in bats strongly suggest that bats exhibit greater muscle mass than quadrupedal mammals of similar size and, furthermore, that musculature required for powered flight in bats exceeds requirements for terrestrial locomotion. 
Insufficient appropriate data exist for comparison with birds.

Total body iron content is essentially identical in bats (Table 2) and birds and both are higher than values in other mammals of similar size (Fig. 1). Because many bats have higher blood volumes, RBC counts and hemoglobin levels than other mammals (Kallen, 1977; Riedesel, 1977), higher total body iron levels in bats are expected. These blood measures are also high in many small birds (Pettingill, 1970), which would also be expected to exhibit total iron levels similar to bats. The presence of higher levels of myoglobin in the predominant slow-twitch cells in the flight musculature of both birds and bats may also contribute to the higher iron levels found in those two groups.

Total body contents of sodium and potassium are similar to each other, in that each element in birds increases somewhat less rapidly with size than in bats and other mammals (Table 2; Fig. 1). These differences are minimal among small ( $<40$ g DM) species and become progressively more pronounced in larger species, where bat body content exceeds levels in other mammals. Similarities in total body content of these minerals are expected since sodium is the primary extracellular fluid cation and potassium is the primary intracellular cation in both birds and mammals.

Among the small ( $<40 \mathrm{~g} \mathrm{DM}$ ) endothermic vertebrates compared, no differences were found in the increases of both calcium and magnesium contents with size (Table 2; Fig. 2). Large bats contain more of both minerals than other mammals or birds of similar size. Because magnesium and calcium are highly sequestered in the skeleton, differences were expected among the three groups tested based on variations in supportive characteristics of skeletons of quadrupeds and physical demands that sustained flight impose on the skeleton. Higher contents of these minerals in very large bats suggest that they store proportionately more of the calcium and magnesium needed for reproduction. Additionally, increased wing loading in larger bats that employ greater flight speeds (Findley et al., 1972) may increase skeletal physical stresses of flight disproportionately in very large bats but not birds.

In summary, fat and total organic content, although quite variable, decrease and water content increases with increasing body size expressed. Although body fat levels in tropical bats are routinely lower than in temperate species, occasional species, e.g. Chiroderma villosum, especially females, show much higher fat concentrations than other tropical species. Except for iron, where no relationship exists, concentrations of other measured elements increase with increasing body DM. Sodium

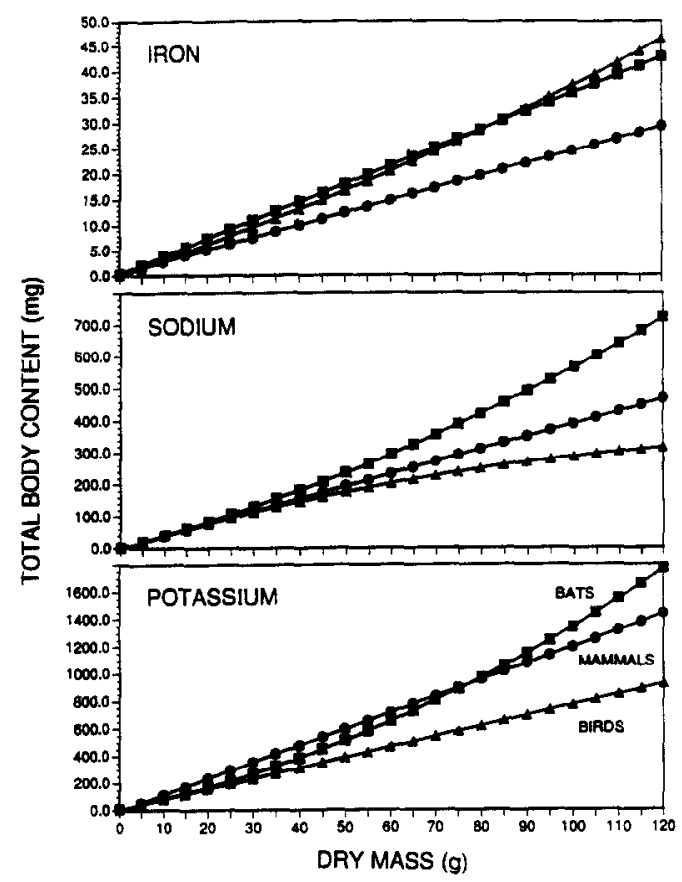

Fig. 1. Solutions to regression equations relating total body iron (top), sodium (middle) and potassium (bottom) content (in $\mathrm{mg}$ ) to body size (dry mass $=\mathrm{DM}$ in $\mathrm{g}$ ) in bats (squares), other small mammals (circles) and small birds (triangles). Equations for bats (24 species) are given in Table 2. For other small mammals (rodents and insectivores), linear regression equations for 25 or 26 species are given by Gentry et al. (1975). Polynomial regression equations (coefficients $\pm S E$ ) for small birds (21-24 species) were calculated from average values reported by Bilby and Widdowson (1971), Sturges et al. (1975), Hagen et al. (1976), Pinowski et al. (1983), and Taylor and Konarzewski (1992). In birds, total body iron content $=0.000765 \pm 0.000187$ $\mathrm{DM}^{2}+0.294 \pm 0.027 \mathrm{DM}+0.0904 \pm 0.2480 \quad(F=$ 4164.; d.f. $\left.=20 ; P<0.0001 ; r^{2}=0.998\right)$; sodium content $=-0.0124 \pm 0.0017 \mathrm{DM}^{2}+4.12 \pm 0.25 \mathrm{DM}+$ $0.771 \pm 2.558 \quad(F=1186 ; \quad$ d.f. $=23 ; \quad P<0.0001$; $\left.r^{2}=0.991\right) ;$ and potassium content $=7.690 \pm 0.076$ $\mathrm{DM}+4.85 \pm 3.31(F=10334$.; d.f. $=23 ; P<0.0001$; $\left.r^{2}=0.998\right)$. 


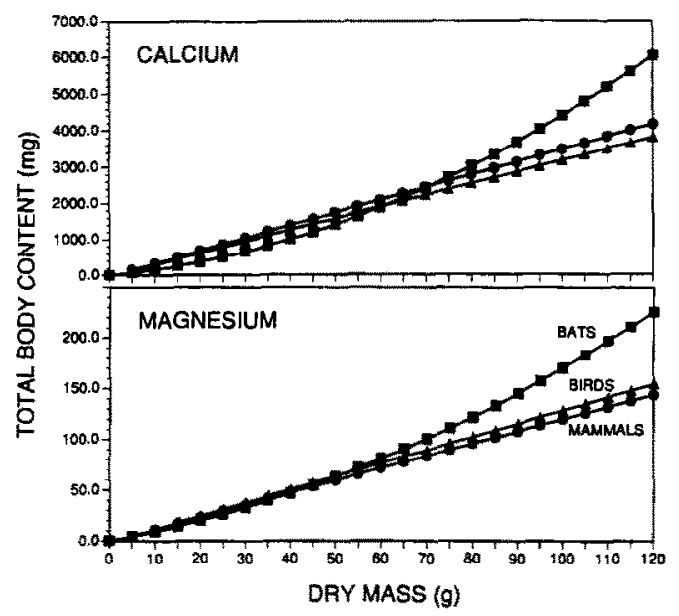

Fig. 2. Solutions to regression equations relating total body calcium (top) and magnesium (bottom) content (in $\mathrm{mg}$ ) in relation to body size (dry mass $=\mathrm{DM}$ in $\mathrm{g}$ ) in bats, other small mammals, and small birds. See legend for Fig. 1 for more details. In birds, total body calcium content $=32.0 \pm 0.6$ $\mathrm{DM}+19.0 \pm 18.5$ ( $F=2801$.; d.f. $=23 ; P<0.0001$; $\left.r^{2}=0.992\right)$, and total body magnesium content $=1.31 \pm 0.02 \quad \mathrm{DM}-1.56 \pm 0.48 \quad(F=7021$; d.f. $\left.=23 ; P<0.0001 ; r^{2}=0.997\right)$.

levels in large bats are higher than in other mammals, whose sodium levels are higher than in similar-sized birds. Magnesium and calcium increase most rapidly in very large bats but are otherwise similar in all three groups. Total body potassium tends to be lower in birds than in similar-sized bats and other mammals. Total body iron content is higher in birds and bats than in other mammals of similar size. Mineral compositions, therefore, do not consistently align bats with other (tetrapodal) mammals or flying endotherms (birds).

Acknowledgements - We thank James Dale Smith and other members of the 1979 Taylor South Seas Expedition from the Natural History Museum of Los Angeles County for sending us samples of the paleotropical bats and associated data. Richard Mills of International Expeditions and Peter Jenson of Explorama Tours provided logistical support for which we are very grateful. We thank Jeffrey LeFleur, Katherine Mattais, Brenda Sandy Flores, and Heather McNamara for help in the laboratory. Dr Robert E. Ricklefs provided useful comments on this manuscript. This study was supported in part by a Faculty Development Grant from The University of Michigan-Flint. This is contribution number 80 of the Biological Diversity of Latin America Program of the Smithsonian Institution's National Museum of Natural History.

\section{References}

Anderson J, F., Rahn H. and Prange H. D. (1979) Scaling of supportive tissue mass. Q. Rev. Biol. 54, $139-148$.

Arita H. T. and Wilson D. E. (1987) Long-nosed bats and agaves: The tequila connection. Bats $\mathbf{5}$, 3-5.

Bilby L. W. and Widdowson E. M. (1971) Chemical composition of growth in nestling blackbirds and thrushes, Br. J. Nutr. 25, 127-134.

Cummins K. W. and Wuycheck J. C. (1971) Caloric equivalents for investigation in ecological energetics. Mitt. Int. Verein. Limnol. 18, 1-158.

Findley J. S., Studier E. H. and Wilson D. E. (1972) Morphological properties of bat wings. J. Mammal. 53, 429-444.

Gardner A. L. (1977) Feeding habits. In Biology of Bats of the New World Family Phyllostomatidae. Part II. (Edited by Baker R. J., Jones J. K. Jr and Carter D. C.), pp. 293-350. Special Publications of the Museum, Texas Tech University, Lubbock, TX.

Gentry J. B., Briese L. A., Kaufman D. W., Smith M. H. and Weiner J. G. (1975) Elemental flow and standing crops for small mammal populations. In Small Mammals: Their Productivity and Population Dynamics (Edited by Golley F. B., Petrusewicz K. and Ryszkowski L.), pp. 205-221. IBP 5. Cambridge University Press, Cambridge.

Hagen J., Hagen A., Ostbye E. and Skar H.-J. (1976) Some chemical elements in the body of the meadow pipit, Anthus pratensis (L). Norweg. J. Zool. 24, 279-289.

Holmes R. T. (1976) Body composition, lipid reserves and caloric densities of summer birds in a northern deciduous forest. Am. Midl. Nat. 96, 281-290.

Hungerford, B. S., Studier E. H., Szuch E. J., Pace G. L. and Taylor S. (1993) Aspects of caloric, nitrogen, and mineral nutrition during growth in nestling eastern bluebirds, Sialia sialis. Comp. Biochem. Physiol. 106A, 385-389.

Kallen F. C. (1977) The Cardiovascular systems of Bats: Structure and Function. In Biology of Bats, Vol. III (Edited by Wimsatt W. A.), Chap. 3, pp. 289-483. Academic Press, New York.

Kayser C. and Heusner A. (1964) Etude comparative du metabolisms energetique dans la serie animale. J. Physiol. (Paris) 56, 489-524.

McNab B. K. (1976) Seasonal fat reserves of bats in two tropical environments. Ecology 57, 332-338.

Munro H. N. (1969) Evolution of protein metabolism in mammals. In Mammalian Protein Metabolism, Vol. III (Edited by Munro H. N.), pp. 133-182. Academic Press, New York.

Peters R. H. (1983) The Ecological Implications of Body Size. Cambridge University Press, Cambridge.

Pettingill O. S. Jr (1970) Ornithology in Laboratory and Field Fourth Edition, Burgess Publishing Company, Minneapolis, Minn.

Pierson E. D. and Stack M. H. (1988) Methods of body composition analysis. In Ecological and Behavioral Methods for the Study of Bats (Edited by Kunz T. H.), Chap. 23, pp. 387-403, Smithsonian Institution Press, Washington, D.C. 
Pinowski J., Pinowska B., Krasnicki K. and Tomek T. (1983) Chemical composition of growth in nestling rooks Corvus frugilegus. Ornis Scand. 14, 289-298.

Prange H. D., Anderson J. F. and Rahn H. (1979) Scaling of skeletal mass to body mass in birds and mammals. Am. Nat. 113, 103-122.

Randolph J. C., Cameron G. N. and Wrazen J. A. (1991) Dietary choice of a generalist herbivore, Sigmodon hispidus. J. Mammal. 72, 300-313.

Reynolds W. W. and Karlotski W. J. (1977) The allometric relationship of skeletal weight to body weight in teleost fishes: A preliminary comparison with birds and mammals. Copeia 1977, 160-163.

Riedesel M. L. (1977) Blood Physiology. In Biology of Bats, Vol. III (Edited by Wimsatt, W. A.), Chap. 4, pp. 485-517. Academic Press, New York.

Studier E. H. (1970) Evaporative water loss in bats. Comp. Biochem. Physiol. 35A, 935-943.

Studier E. H. (1979) Bioenergetics of growth, pregnancy and lactation in the laboratory mouse, Mus musculus. Comp. Biochem. Physiol. 64A, 473-481.

Studier E. H., Dapson R. W. and Bigelow R. E. (1975) Analysis of polynomial functions for determining maximum or minimum conditions in biological systems. Comp. Biochem. Physiol. 52A, $19-20$.

Studier E. H. and Kunz T. H. (1994) Nitrogen and mineral accretion in suckling bats, Myotis velifer and Tadarida brasiliensis. J. Mammal (in press).

Studier E. H. and Sevick S. H. (1992) Live mass, water content, nitrogen and mineral levels in some insects from south-central lower Michigan. Comp. Biochem. Physiol. 103A, 579-595.

Studier E. H. and Wilson D. E. (1991) Physiology. In Demography and Natural History of the Common Fruit Bat, Artibeus jamaicensis, on Barro Colorado Island, Panama (Edited by Handley C. O., Wilson D. E. and Gardner A. L.), Chap. 2, pp. 9-17. Smithsonian Contributions to Zoology, Number 511, Smithsonian Institution Press, Washington, D.C.

Sturges F. W., Holmes R. T. and Likens G. E. (1974) The role of birds in nutrient cycling in a northern hardwoods ecosystem. Ecology 55, 149-155.

Taylor J. R. E. and Konarzewski M. (1992) Budget of elements in little auk (Alle alle) chicks. Funct. Ecol. 6, 137-144.

Treybig D. S. and Haney P. L. (1983) Colorimetric determination of total nitrogens in amines with selenium catalyst. Analyt. Chem. 55, 983-985.

Wilkinson L. (1989) SYSTAT: The System for Statistics. SYSTAT, Evanston, IL.

Willig M. R. and Lacher T. E. Jr (1991) Food selection of a tropical mammalian folivore in relation to leaf-nutrient content. J. Mammal. 72, 314-321. 


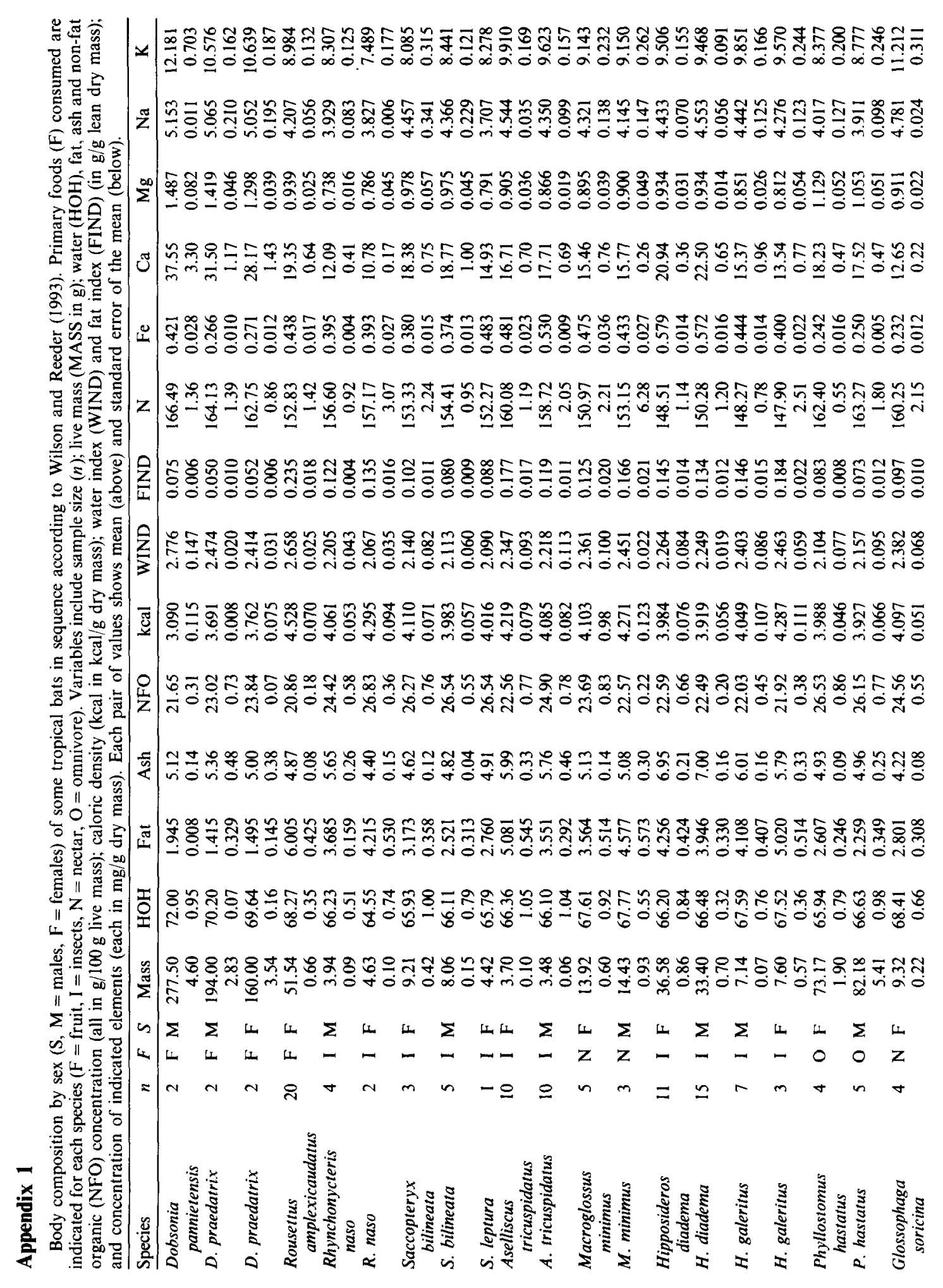




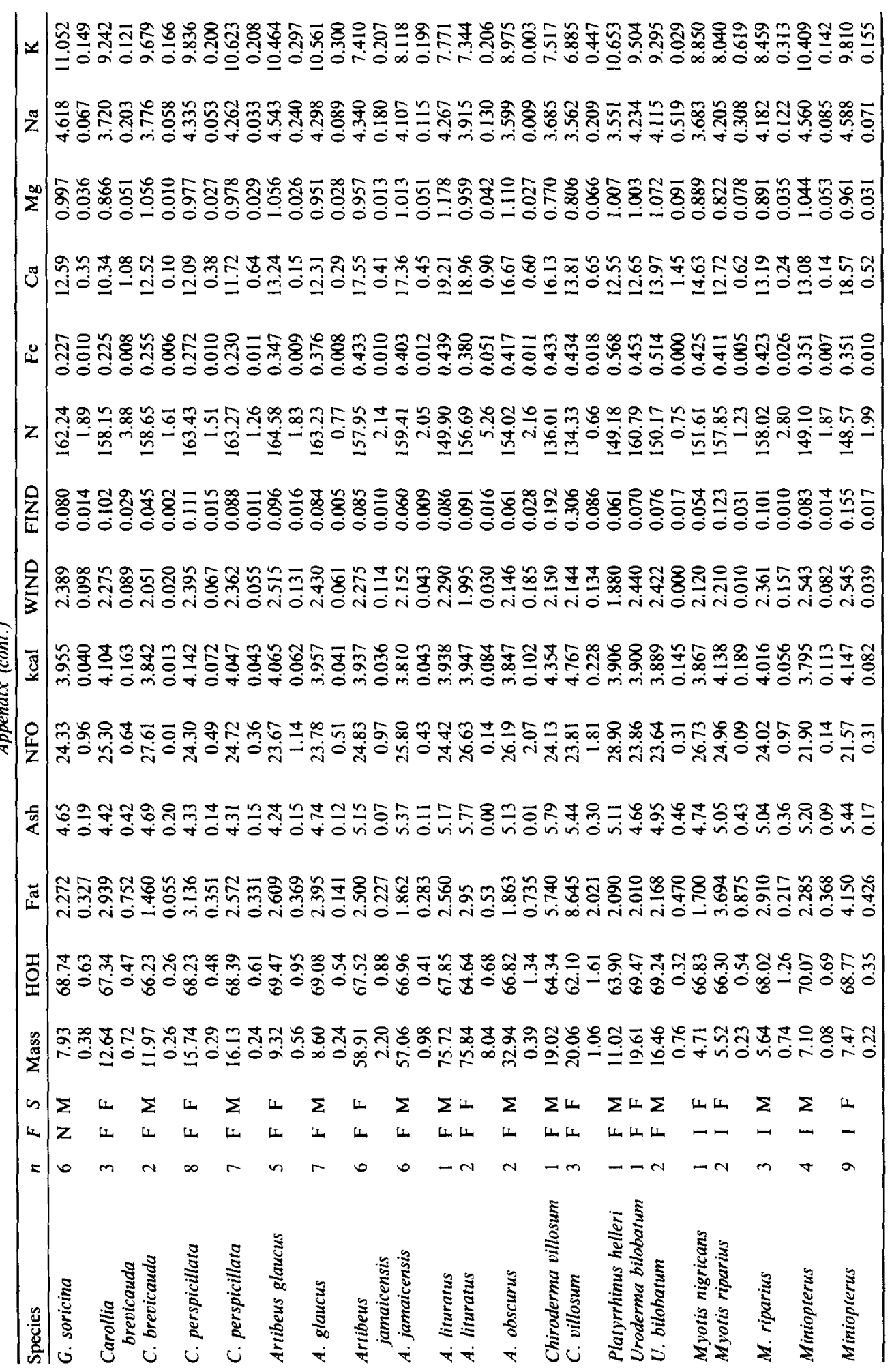

